\title{
PHYSICAL AND MECHANICAL PROPERTIES OF HEAT TREATED WOOD FROM Aspidosperma populifolium, Dipteryx odorata AND Mimosa scabrella
}

\author{
Solange de Oliveira Araújo ${ }^{1, \star}$, Benedito Rocha Vital $^{2}$, Braulio Oliveira $^{2}$, Angélica de Cássia \\ Oliveira Carneiro ${ }^{2}$, Ana Lourenço ${ }^{1}$, Helena Pereira ${ }^{1}$
}

\begin{abstract}
Heat treatment improves some wood properties namely: equilibrium moisture, dimensional stability and durability and mechanical properties. In this study, the heat treatment was applied to woods of three natural species from Brazil: Aspidosperma populifolium (peroba mica), Dipteryx odorata (cumaru) and Mimosa scabrella (bracatinga). The woods were heated in an oven under vacuum and under nitrogen, at 180,200 , and $220^{\circ} \mathrm{C}$ for one hour. The untreated and heat-treated woods were characterized in relation to equilibrium moisture content, basic density, shrinkage, Janka hardness, and bending MOR and MOE according to NBR 7190 standards. All the thermal rectified woods showed a reduction in the hygroscopic equilibrium content, especially when the heating was under vacuum from $13-15 \%$ in the untreated woods to $1-3 \%$ for vacuum treatment at $220^{\circ} \mathrm{C}$. The dimensional stability was improved to only a small extent e.g. volumetric shrinkage tended to decrease with increasing temperature. The mechanical properties were affected differently for the three wood species. Heat-treated cumarushowed increased Janka hardness, MOR and MOE; and peroba mica increased MOR and MOE but not Janka hardness; while bracatinga was less influenced by the heat treatment.
\end{abstract}

Keywords: Aspidosperma populifolium, Dipteryx odorata, equilibrium moisture content, mechanical properties, Mimosa scabrella, nitrogen heat treatment, vacuum heat treatment.

\section{INTRODUCTION}

Wood is a material with excellent mechanical behavior, namely considering its performance-todensity ratio, but also with some undesirable properties such as hygroscopicity, anisotropy, dimensional instability and biodegradability (Tomak et al. 2011, Miller 1999). Thermal modification processes are used to improve the wood quality and are especially targeted to increase durability and dimensional stability, and decrease equilibrium moisture content (Esteves and Pereira 2009). The heat-treated wood can therefore be applied for higher value end-uses such as surfacing, floors, windows and doors, musical instruments, boats, and general outdoor uses (Gunduz 2009).

Thermal modification is performed by heating the wood at temperatures between 180 and $260{ }^{\circ} \mathrm{C}$, usually in the absence of oxygen or with air deficiency (Homan 2004). In these conditions, there are chemical changes e.g. degradation of hemicelluloses and extractives, to an extent that depends on the wood species and on the treatment intensity, for example under $140{ }^{\circ} \mathrm{C}$ only slight changes occur while above $260{ }^{\circ} \mathrm{C}$ the substantial degradation of the structural components lowers the wood properties (Batista et al. 2011, Mitchel 1988, Hill 2006, Esteves and Pereira 2008a). 
Thermal modification has been applied to different species, mostly hardwoods and softwoods from temperate regions. Few species from tropical and subtropical regions have undergone thermal treatment: Pinus caribaea var. hondurensis, between 120 and $180^{\circ} \mathrm{C}$ (Borges and Quirino 2005), Eucalyptus grandis between 120 and $200{ }^{\circ} \mathrm{C}$ (Brito et al. 2006) and Corymbia citriodora between 200 and $220^{\circ} \mathrm{C}$ (Nunes 2009), while Eucalyptus grandis, Pinus taeda and Tectona grandis were heat treated at $160^{\circ} \mathrm{C}$ at industrial scale (Lengowski 2011). The Brazilian native species Simarouba amara, Sextonia rubra and Cariniana micrantha were also treated at 150 and $200{ }^{\circ} \mathrm{C}$ to reduce surface color variation (Gouveia 2008).

This work studies three species occurring naturally in Brazil and with economic importance for the furniture and flooring industry.

Mimosa scabrella Bentham (common name bracatinga) is a native forest species in Brazil, occurring in cold and wet areas, mainly in the states of Minas Gerais, Paraná, Rio de Janeiro, Santa Catarina, Rio Grande do Sul and São Paulo. The wood has a medium density (510 to $\left.610 \mathrm{~kg} \mathrm{~m}^{-3}\right)$, low durability when in contact with the ground, and low permeability towards preservative products (Sturion and Silva 1989, Inoue et al. 1984). It is used for firewood, charcoal, plywood, particleboard and lightweight containers and, more recently, started to be introduced in furniture and flooring (Baggio et al. 1986, Baggio and Carpanezzi 1998).

Aspidosperma populifolium (common name peroba mica) is distributed naturally in the Amazon region and center-west of Brazil, in the states of Amazonas, Pará, Rondônia and Mato Grosso. The wood is density $\left(730 \mathrm{~kg} \mathrm{~m}^{-3}\right)$ and used in construction, as beams, rafters and slats for floors, carpentry and high quality furniture manufacturing.

Dipteryx odorata (common name cumaru) is frequent in the states of Acre, Amapá, Amazonas, Pará, Rondônia and Mato Grosso, as well as in neighboring countries like Guyana, Venezuela, Colombia, Bolivia, Peru and Suriname. The wood is very dense $\left(950-1000 \mathrm{~kg} \mathrm{~m}^{-3}\right)$, tough, highly durable and resistant to cracking when exposed to sunlight, therefore is suitable for solid flooring, stair treads, furniture, and pool decks (Loureiro et al. 1979).

In this work the wood of these three species (Aspidosperma populifolium, Dipteryx odorata, Mimosa scabrella) was thermally treated and the effect of temperature and treatment methods (vacuum and nitrogen environments) was evaluated in relation to equilibrium moisture, basic density, shrinkage, Janka hardness and bending strength. The aim is to improve the wood properties of these three species in order to target them towards high-quality solid timber products.

\section{MATERIALS AND METHODS}

\section{Samples}

The commercial woods: bracatinga (Mimosa scabrella Bentham), peroba mica (Aspidosperma populifolium A. DC) and cumaru (Dipteryx odorata (Aubl.) Wiilld) were used in this study. The boards were donated by Indusparket (Tietê, São Paulo, Brazil), a national manufacturer of hardwood floors. The boards were air dried to moisture content between 12 and $15 \%$. Test samples were cut with $60 \mathrm{~cm}$ $\mathrm{x} 7,5 \mathrm{~cm} \times 2 \mathrm{~cm}$ (length $\mathrm{x}$ width $\mathrm{x}$ thickness, corresponding to the axial, tangential and radial directions of the wood).

The experiments were conducted in the laboratories of the Panels and Wood Energy (LAPEM), Pulp and Paper (LCP) and Wood Properties (LPM), of the Federal University of Viçosa, Brazil. 


\section{Thermal treatment}

The wood samples were thermally treated in a Marconi vacuum oven Model MA-027 (São Paulo, Brazil), fitted with temperature and pressure, or vacuum, control. The oven internal chamber has a cylindrical shape $(30 \mathrm{~cm}$ diameter and $70 \mathrm{~cm}$ length) and a support platform where the wood samples are stacked. The oven allowed the control of temperature, the choice of input gas e.g. air or nitrogen, and the variation of the inside pressure by connection to a vacuum pump.

Preceding each heat treatment, the samples were weighed and measured (length, width and thickness) for later calculation of mass loss and volume variation. The mass loss was determined for each sample in relation to its initial oven-dry mass in accordance to the equation 1:

$$
\operatorname{Mass} \operatorname{loss}(\%)=\frac{(\text { wood mass }- \text { treated wood mass })}{\text { wood mass }} \times 100(\text { Equation } 1)
$$

where the wood mass is the oven-dry weight of the specimen without treatment $(\mathrm{g})$, and the treated wood mass corresponds to the oven-dry weight of the specimen after heat treatment (g).

The oven was conditioned to the environment conditions under testing, and heated until the treatment temperature was attained; the samples were then rapidly put inside, and heated during one hour at constant temperature. The temperatures tested were 180,200 and $220^{\circ} \mathrm{C}$. Two oven conditions were evaluated: i) the air filled oven was evacuated with the coupled vacuum pump to a pressure of $0,06 \mathrm{MPa}$ (here called "vacuum" treatment); ii) the oven was filled with nitrogen and then evacuated with the coupled vacuum pump to a pressure of $0,06 \mathrm{MPa}$ (here called "nitrogen" treatment).

Each experiment used six wood samples for each species. After treatment, the samples were removed and cooled to $25{ }^{\circ} \mathrm{C}$, weighed, measured (width, thickness and length) and kept at ambient temperature and humidity. Posteriorly, the samples were weighed and measured weekly until they reached equilibrium moisture content that was attained after eight weeks.

\section{Wood properties}

The following properties were determined in untreated and heat treated wood samples: equilibrium moisture content, basic density, shrinkage, Janka hardness and bending strength. The specimens for each test were prepared according to NBR 7190 (ABNT 1997) standards. Before testing, all the samples were conditioned in a climate chamber at $20{ }^{\circ} \mathrm{C}$ and $65 \%$ relative humidity.

Hygroscopicity was evaluated by the equilibrium moisture content after stabilization in a controlled environment at $20 \pm 2{ }^{\circ} \mathrm{C}$ and $65 \%$ relative humidity.

Wood basic density was determined according to adaptation of Tappi 258 om-02 standard, and calculated by dividing the oven dried mass by the saturated volume, using the standard immersion method for volume determination. The dry mass was determined after oven dry at $103{ }^{\circ} \mathrm{C}$ until constant weight.

The test specimens were cut to a prismatic shape with a rectangular cross section of $2 \mathrm{~cm} \times 3 \mathrm{~cm}$ (radial $\mathrm{x}$ tangential) and $5 \mathrm{~cm}$ length (axial). Eighteen replicates of untreated and treated specimens were used for each test (three different temperatures, two different methods, three species), totaling 108 samples ( 6 wood samples x 18 replicates) for each test and by species. The other physical and mechanical tests were made with the same number of specimens. 
The dimensional stability of the wood is characterized by the properties of shrinkage and swelling that should be determined in the tangential, radial and axial directions. The shrinkage was determined from a saturated state to an oven dry state, andcalculated as percent variation in relation to the saturated state. The volume variation was determined with the dimensions of the samples in the dry and saturated states as in equation 2:

$$
\mathrm{S}_{\mathrm{vol}}=\frac{\mathrm{V}_{\mathrm{w}}-\mathrm{V}_{\mathrm{d}}}{\mathrm{V}_{\mathrm{w}}} \times 100 \text { (Equation 2) }
$$

Where $\mathrm{S}_{\mathrm{vol}}$ is the total volumetric shrinkage $(\%) ; \mathrm{V}_{\mathrm{w}}$ is the saturated volume $\left(\mathrm{cm}^{3}\right)$; and $\mathrm{V}_{\mathrm{d}}$ the oven dry volume $\left(\mathrm{cm}^{3}\right)$.

The samples were placed in a saturated environment at $20^{\circ} \mathrm{C} \pm 5^{\circ} \mathrm{C}$, until the dimensional variation stabilized (differences of $0,02 \mathrm{~mm}$ between two successive measurements were accepted).

The anisotropy coefficient (AC) was calculated by dividing the tangential shrinkage (TC, \%) by the radial shrinkage (RC, \%), as follows

$$
A \mathrm{C}=\frac{\mathrm{TC}}{\mathrm{RC}} \quad(\text { Equation } 3)
$$

The Janka wood hardness teste was determined by the ratio between the maximum force (in $\mathrm{N}$ ) applied for a required penetration into the wood of a sphere with $1 \mathrm{~cm}^{2}$ diametrical section at a depth equal to its radius. The wood specimens were prismatic with a square of $5 \mathrm{~cm}$ in cross-section (radial $\mathrm{x}$ tangential) and a length (axial) of $15 \mathrm{~cm}$. For the application of the Janka Hardness test, the specimens were glued together with adhesive (resorsinol) in order to have a square area of $5 \mathrm{~cm}^{2}$ in the sample cross-section.

Bending was characterized by the flexural modulus of rupture (MOR) and modulus of elasticity (MOE), and the results were reported in $\mathrm{MPa}$. The wood specimens for the bending tests had a prismatic square shape of $2 \mathrm{~cm}$ across (radial $\mathrm{x}$ tangential) and a length of $30 \mathrm{~cm}$ (axial). The mechanical test was performed on a computer controlled universal testing machine CONTENCO (Minas Gerais, Brazil). The specimens were supported on two articulated cleavers, with a span of $24 \mathrm{~cm}$, and the load was applied by means of a cleaver directly in the center of the specimen, tangentially to the growth rings. The load was increased gradually and steadily, allowing the measurement of the deflection at each increment until rupture.

\section{RESULTS AND DISCUSSION}

\section{Equilibrium moisture content}

Table 1 presents the average values of the equilibrium moisture content in the untreated and in the heat-treated samples. The untreated woods had equilibrium moisture values ranging from $13,1 \%$ (cumaru) to $15,5 \%$ (bracatinga) that decreased significantly upon thermal treatment. In all cases, the heat-treated wood samples significantly differed from the untreated wood (Table 1).

The reduction extent of the equilibrium moisture content was influenced by the method used for the thermal treatment: under vacuum, the reduction was much higher than under a nitrogen environment for the same temperature e.g. 3,3\% vs. $12,8 \%$ for vacuum and nitrogen treatment for bracatinga wood at $180{ }^{\circ} \mathrm{C}$, respectively (Table 1). Temperature also influenced the equilibrium moisture content, although the differences between treatments at $180^{\circ} \mathrm{C}$ and $220^{\circ} \mathrm{C}$ were small. The analysis of variance indicated that method and temperature within the method were significant factors of variation of the wood equilibrium moisture content, although in most cases there was no statistical significant variation between temperatures (Table 1). 
Comparison of the three species showed a similar behavior both regarding temperature as well as the method. It is noteworthy that the three heat-treated woods under vacuum attained very low equilibrium moisture contents: bracatinga $2,7 \%$, peroba mica $1,2 \%$ and cumaru $1,3 \%$. In the treatment under vacuum there was already a major effect at $180^{\circ} \mathrm{C}$.

Table 1. Hygroscopicity (equilibrium moisture content, \%) of bracatinga, peroba mica and cumaru woods after heat treatment at three temperatures $\left(180,200\right.$ and $\left.220^{\circ} \mathrm{C}\right)$ under two methods (vacuum and $\mathrm{N}_{2}$ ).

\begin{tabular}{cccc} 
& & \multicolumn{2}{c}{ Method } \\
\hline Wood & Temperature $\left({ }^{\circ} \mathbf{C}\right)$ & Vacuum & Nitrogen \\
\hline \multirow{2}{*}{ Bracatinga } & Untreated & $15,5 \mathrm{a}$ & $15,5 \mathrm{a}$ \\
(Mimosa scabrella) & $\mathbf{1 8 0}$ & $3,3 \mathrm{~b}$ & $12,8 \mathrm{~b}$ \\
& $\mathbf{2 0 0}$ & $2,8 \mathrm{c}$ & $12,6 \mathrm{~b}$ \\
& $\mathbf{2 2 0}$ & $2,7 \mathrm{c}$ & $11,6 \mathrm{c}$ \\
\hline \multirow{2}{*}{ Peroba mica } & Untreated & $14,9 \mathrm{a}$ & $14,9 \mathrm{a}$ \\
(Aspidosperma & $\mathbf{1 8 0}$ & $2,1 \mathrm{~b}$ & $11,5 \mathrm{~b}$ \\
populifolium) & $\mathbf{2 0 0}$ & $1,5 \mathrm{~b}$ & $11,2 \mathrm{~b}$ \\
& $\mathbf{2 2 0}$ & $1,2 \mathrm{c}$ & $10,3 \mathrm{c}$ \\
\hline \multirow{2}{*}{ Cumaru } & Untreated & $13,1 \mathrm{a}$ & $13,1 \mathrm{a}$ \\
$($ Dipteryx odorata) & $\mathbf{1 8 0}$ & $1,4 \mathrm{~b}$ & $10,1 \mathrm{~b}$ \\
& $\mathbf{2 0 0}$ & $1,5 \mathrm{~b}$ & $10,1 \mathrm{~b}$ \\
& $\mathbf{2 2 0}$ & $1,3 \mathrm{~b}$ & $9,4 \mathrm{~b}$
\end{tabular}

Values with the same letters along the columns do not differ by Tukey test at $5 \%$ probability.

Similar results have been observed by researchers studying wood thermal modification; in fact, the decrease of wood hygroscopicity is considered as one of the greatest benefits provided by the thermal wood modification (Hill 2006, Esteves and Pereira 2009). The decrease of hygroscopicity in thermally treated woods may be explained by a lower water absorption by the cell walls due to the partial removal of extractives and of hemicelluloses that reduces the hydrophilic hydroxyl groups, with an increase of cellulose crystallinity and of linkages in the lignin matrix (Esteves et al. 2008a, Sundqvist 2004, Boonstra and Tjeerdsma 2006). The treatment under vacuum favored the transfer of volatiles to the gas phase (Candelier et al. 2013), therefore yielding a more hydrophobic wood, as shown by the results in Table 1 . The same influence of a vacuum environment leading to a sharp decrease of the equilibrium moisture content with the heat treatment was also reported using the same equipment (Araújo et al. 2014).

\section{Basic density and mass loss}

The wood basic density was different between the three species: the lower value was attained by bracatinga $\left(550 \mathrm{~kg} \mathrm{~m}^{-3}\right)$, while peroba mica $610 \mathrm{~kg} \mathrm{~m}^{-3}$; and the higher value was obtained by cumaru, $900 \mathrm{~kg} \mathrm{~m}^{-3}$. 
The thermal treatment influenced the wood density only in a small extent as can be seen in Figure 1. Bracatinga wood showed a small increase in wood density after the heat-treatment,e.g increased to $58 \mathrm{~kg} \mathrm{~m}^{-3}$ for the different methods and temperatures; for peroba mica the wood basic density increased slightly to $630 \mathrm{~kg} \mathrm{~m}^{-3}$ for the heat-treated sample at $220{ }^{\circ} \mathrm{C}$; while in cumaru wood the variation was also small e.g. $890 \mathrm{~kg} \mathrm{~m}^{-3}$ in the sample treated at $220{ }^{\circ} \mathrm{C}$ treatment under nitrogen.

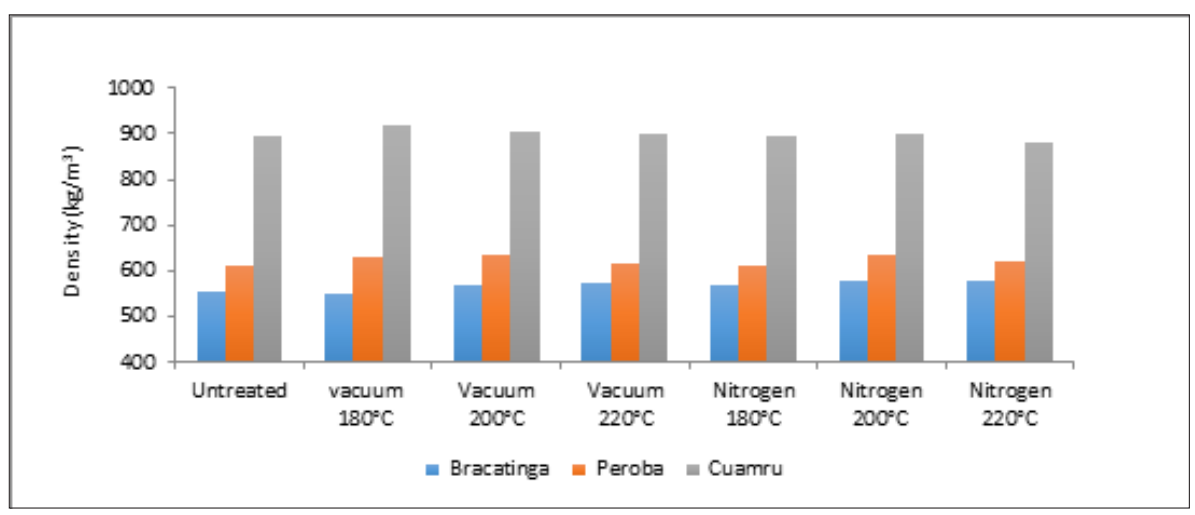

Figure 1. Basic density of wood samples of Aspidosperma populifolium (peroba mica), Dipteryx odorata (cumaru) and Mimosa scabrella (bracatinga) after heat treatment at three temperatures (180, 200 and $220^{\circ} \mathrm{C}$ ) under two methods (vacuum and $\mathrm{N}_{2}$ ).

Temperature is usually considered to induce a decrease of the wood basic density due to mass loss (Boonstra et al. 2007), but response to particular treatment may differ (Tomazello Filho 1985, Garcia 1995). This was found previously for the heat treatmentof eucalypt wood using the same equipment and conditions as in this study (Araújo et al. 2014).

The mass loss was different between the three species and two methods (Table 2). Mass loss of wood is related to its thermal degradation and appears to be the indicator of the treatment intensity. Since the properties of heat treated wood depend on the mass loss (Weiland et al. 1998) the control of the mass loss during the treatment is a quality factor.

The mass loss values were overall small. Mass loss increased when temperature increased for both methods. This has been shown for instance by Allegretti et al. (2012) who refer mass loss of 1\% at 160 ${ }^{\circ} \mathrm{C}$ and $6-7 \%$ at $220{ }^{\circ} \mathrm{C}$ for Norway spruce (Picea abies) and fir (Abies alba). In this work, the values of mass loss found for $220^{\circ} \mathrm{C}$ were lower, presumably due to the heat short treatment time $(1 \mathrm{~h})$. In fact, the comparison of data from different authors is often difficult due to differences in treatment duration and other factors involved. 
The mass loss values were lower for the treatment with nitrogen than for that with vacuum for all temperatures and species. This was an expected result because under nitrogen the medium is deficient in oxygen, there by reducing the oxidative reactions which interfere with the wood components.

Under vacuum, the mass loss remained of small magnitude since all volatile degradation products like acetic acid or furfural were removed as soon as they were formed thereby limiting the degradation of wood polysaccharides and their recondensation through thermoreticulation and crosslinking reactions (Candelier et al. 2013).

Table 2. Mass loss (\%) of bracatinga, peroba mica and cumaru wood samples after thermal treatment at three temperatures $\left(180,200\right.$ and $220^{\circ} \mathrm{C}$ ) and using two methods (vacuum and $\mathrm{N}_{2}$ ).

\begin{tabular}{cccc}
\hline \multirow{2}{*}{ Wood } & \multirow{2}{*}{ Temp $\left.^{\circ} \mathbf{C}\right)$} & \multicolumn{2}{c}{ Method } \\
\cline { 3 - 4 } & $\mathbf{1 8 0}$ & 1,24 & Vitrogen \\
\hline \multirow{2}{*}{ Bracatinga } & $\mathbf{2 0 0}$ & 1,61 & 0,22 \\
(Mimosa scabrella) & $\mathbf{2 2 0}$ & 2,21 & 0,30 \\
& $\mathbf{1 8 0}$ & 0,68 & 0,41 \\
\hline Peroba Mica & $\mathbf{2 0 0}$ & 1,24 & 0,27 \\
(Aspidosperma & $\mathbf{2 2 0}$ & 1,72 & 0,34 \\
populifolium) & $\mathbf{1 8 0}$ & 0,27 & 0,43 \\
\hline Cumaru & $\mathbf{2 0 0}$ & 0,31 & 0,26 \\
(Dipteryx odorata) & $\mathbf{2 2 0}$ & 0,33 & 0,37 \\
& & & 0,51 \\
\hline
\end{tabular}

\section{Shrinkage of wood}

Table 3 presents the mean values for the axial, tangential, radial and volumetric shrinkage as well as the anisotropy coefficient of the untreated and the thermally treated wood samples. 
Table 3. Dimensional variation of wood samples ofbracatinga, peroba mica and cumaru after heat treatment at three temperatures $\left(180,200\right.$ and $220^{\circ} \mathrm{C}$ ) under two methods (vacuum and $\mathrm{N}_{2}$ ).

\begin{tabular}{|c|c|c|c|c|c|c|c|}
\hline Wood & Method & $\begin{array}{l}\text { Temp } \\
\left({ }^{\circ} \mathrm{C}\right)\end{array}$ & $\begin{array}{c}\text { Axial } \\
\text { shrinkage } \\
(\%)\end{array}$ & $\begin{array}{c}\text { Radial } \\
\text { shrinkage } \\
(\%)\end{array}$ & $\begin{array}{c}\text { Tangential } \\
\text { shrinkage } \\
(\%)\end{array}$ & $\begin{array}{c}\text { Volume } \\
\text { shrinkage } \\
(\%) \\
\end{array}$ & $\begin{array}{c}\text { Anisotropy } \\
\text { coefficient }\end{array}$ \\
\hline \multirow{8}{*}{$\begin{array}{l}\text { Bracatinga } \\
\text { (Mimosa } \\
\text { scabrella) }\end{array}$} & \multirow{4}{*}{ Vacuum } & Untreated & 0,5 & 6,5 & 8,1 & 14,5 & 1,4 \\
\hline & & 180 & 0,4 & 6,8 & 7,9 & 14,6 & 1,3 \\
\hline & & 200 & 0,3 & 6,9 & 8,1 & 14,8 & 1,3 \\
\hline & & 220 & 0,3 & 7,2 & 7,9 & 14,8 & 1,2 \\
\hline & \multirow{4}{*}{ Nitrogen } & Untreated & 0,5 & 6,5 & 8,1 & 14,5 & 1,4 \\
\hline & & 180 & 0,3 & 6,2 & 9,0 & 14,9 & 1,6 \\
\hline & & 200 & 0,4 & 7,7 & 6,9 & 14,4 & 1,0 \\
\hline & & 220 & 0,2 & 6,5 & 7,4 & 14,0 & 1,1 \\
\hline \multirow{8}{*}{$\begin{array}{l}\text { Peroba Mica } \\
\text { (Aspidosperma } \\
\text { populifolium) }\end{array}$} & \multirow{4}{*}{ Vacuum } & Untreated & 0,4 & 5,7 & 6,0 & 11,7 & 1,2 \\
\hline & & 180 & 0,3 & 6,2 & 6,3 & 12,3 & 1,1 \\
\hline & & 200 & 0,3 & 5,5 & 6,1 & 13,4 & 1,4 \\
\hline & & 220 & 0,2 & 5,4 & 6,2 & 11,5 & 1,2 \\
\hline & \multirow{4}{*}{ Nitrogen } & Untreated & 0,4 & 5,7 & 6,0 & 11,7 & 1,2 \\
\hline & & 180 & 0,2 & 4,2 & 6,4 & 10,5 & 1,6 \\
\hline & & 200 & 0,2 & 5,3 & 5,7 & 10,8 & 1,2 \\
\hline & & 220 & 0,2 & 5,3 & 6,5 & 11,6 & 1,3 \\
\hline \multirow{8}{*}{$\begin{array}{l}\text { Cumaru } \\
\text { (Dipteryx } \\
\text { odorata) }\end{array}$} & \multirow{4}{*}{ Vacuum } & Untreated & 0,2 & 4,4 & 6,1 & 10,2 & 1,5 \\
\hline & & 180 & 0,2 & 4,2 & 4,0 & 8,2 & 1,0 \\
\hline & & 200 & 0,3 & 4,6 & 5,1 & 9,6 & 1,2 \\
\hline & & 220 & 0,2 & 4,4 & 5,2 & 9,4 & 1,2 \\
\hline & \multirow{4}{*}{ Nitrogen } & Untreated & 0,2 & 4,4 & 6,1 & 10,2 & 1,5 \\
\hline & & 180 & 0,2 & 4,9 & 5,0 & 9,8 & 1,1 \\
\hline & & 200 & 0,2 & 4,4 & 4,8 & 9,1 & 1,0 \\
\hline & & 220 & 0,2 & 4,1 & 5,2 & 9,2 & 1,4 \\
\hline
\end{tabular}

The untreated wood samples showed shrinkage values in accordance with reported values e.g. very small axial dimensional variation and medium shrinkage in the radial and tangential directions. Bracatinga wood is considered to have high shrinkage values which limit its usage (Moreschi 2005, Galvão and Jankowski 1985) and the values found here were similar to those reported by Costa et al. (2010) and Stamm (1956). The peroba mica wood showed shrinkage values within the range reported by Logsdon (2008) and Lovatti (2008): 3,6 and 6,2\% radial shrinkage; 6,9 and 9,4\% tangential shrinkage; 10,4 and $16,6 \%$ volumetric shrinkage, with 1,98 and 1,51 anisotropy coefficient. Cumaru wood had shrinkage values in accordance with the reported values of 5,4\% radial shrinkage; $8,4 \%$ tangential shrinkage, 12\% volumetric shrinkage and 1,55 coefficient of anisotropy (IBAMA 1997, IBDF 1988, IBDF 1981, Souza et al. 1997).

The heat treatment did not change significantly the dimensional stability of the woods, and the differences in shrinkage values with temperatures and treatment methods were not statistically significant. 


\section{Janka hardness}

Table 4 shows the values obtained for the Janka hardness perpendicular to the grain for the untreated and heat treated wood samples. The untreated woods showed differences in hardness with cumaru wood as the hardest and bracatinga as the less hard (105,6 MPa and 46,7 MPa respectively).

The effect of heating on the wood hardness depended on the species (Table 3). The thermal treatments showed no significant influence on the Janka hardness of bracatinga and peroba mica woods. On the contrary, cumaru wood significantly increased its hardness with the heat treatment, regardless of the heating method or the temperature, which did not impact significantly on the results.

Table 4. Janka hardness (MPa) of bracatinga, peroba mica and cumaru wood samples after thermal treatment at three temperatures $\left(180,200\right.$ and $\left.220^{\circ} \mathrm{C}\right)$ and using two methods (vacuum and $\mathrm{N}_{2}$ ).

\begin{tabular}{llcc}
\hline \multirow{2}{*}{ Wood } & \multirow{2}{*}{ Temp $\left({ }^{\circ} \mathbf{C}\right)$} & \multicolumn{2}{c}{ Method } \\
\cline { 3 - 4 } & Untreated & 46,7 & 46,7 \\
Bracatinga & $\mathbf{1 8 0}$ & 42,7 & 47,9 \\
(Mimosa scabrella) & $\mathbf{2 0 0}$ & 49,1 & 48,4 \\
& $\mathbf{2 2 0}$ & 48,6 & 44,6 \\
\hline \multirow{3}{*}{ Peroba Mica } & Untreated & 61,4 & 61,4 \\
(Aspidosperma populifolium) & $\mathbf{2 0 0}$ & 66,6 & 58,9 \\
& $\mathbf{2 2 0}$ & 60,3 & 60,4 \\
& $\mathbf{1 8 0}$ & 59,5 & 62,2 \\
Cumaru & $\mathbf{1 8 0}$ & 105,7 & 105,7 \\
(Dipteryx odorata) & $\mathbf{2 0 0}$ & 123,5 & 114,1 \\
& $\mathbf{2 2 0}$ & 117,1 & 115,4 \\
& & 115,5 & 114,0 \\
\hline
\end{tabular}

The increase of strength and hardness of thermally treated wood is attributed to chemical condensation between polysaccharides and lignin (Sundqvist 2004). Different reports on Janka hardness variation in thermally treated woods have been given in the literature. Gunduz et al. (2009) observed that with increasing temperature and duration of heat treatment, Janka hardness decreased; while the Finnish Thermowood Association (FTA 2003) indicated that it increases with temperature, and higher treatment temperatures will influence more the wood hardness (Tuong and Li 2011).

\section{Bending resistance}

The heat treatment of the woods influenced their bending behavior, but the sign of the variation depended on the species and treatment type. Bracatinga showed a reduction in the modulus of rupture for the treatment under vacuum but an increase for the treatment under nitrogen, e.g. 105,4 $\mathrm{MPa}$ in untreated wood, and $96 \mathrm{MPa}$ and $113,5 \mathrm{MPa}$ for the $220^{\circ} \mathrm{C}$ treatment under vacuum and nitrogen respectively. MOE was lower for the treatment under vacuum but had no significant differences under nitrogen (Table 5). 
Table 5. Modulus of elasticity (MOE) and modulus of rupture (MOR) of bracatinga wood samples after thermal treatment at three temperatures $\left(180,200\right.$ and $\left.220^{\circ} \mathrm{C}\right)$ and using two methods (vacuum and nitrogen).

\begin{tabular}{|c|c|c|c|c|c|}
\hline \multirow{3}{*}{ Wood } & \multirow{3}{*}{$\begin{array}{c}\text { Temperature } \\
\left({ }^{\circ} \mathbf{C}\right)\end{array}$} & \multicolumn{4}{|c|}{ Method } \\
\hline & & \multicolumn{2}{|c|}{ Vacuum } & \multicolumn{2}{|c|}{ Nitrogen } \\
\hline & & $\begin{array}{l}\text { MOR } \\
(\mathrm{MPa})\end{array}$ & $\begin{array}{l}\mathrm{MOE} \\
(\mathrm{MPa})\end{array}$ & $\begin{array}{l}\text { MOR } \\
(\mathrm{MPa})\end{array}$ & $\begin{array}{l}\mathrm{MOE} \\
(\mathrm{MPa})\end{array}$ \\
\hline \multirow{4}{*}{$\begin{array}{l}\text { Bracatinga } \\
\text { (Mimosa scabrella) }\end{array}$} & Untreated & $105,4 \mathrm{a}$ & $9437 \mathrm{a}$ & $105,4 \mathrm{~b}$ & $9437 \mathrm{a}$ \\
\hline & 180 & $87,9 \mathrm{c}$ & $6829 \mathrm{bc}$ & $108,7 \mathrm{ab}$ & $9511 \mathrm{a}$ \\
\hline & 200 & $96,3 \mathrm{~b}$ & $7006 \mathrm{~b}$ & $107,3 \mathrm{ab}$ & $9361 \mathrm{a}$ \\
\hline & 220 & $96,0 \mathrm{~b}$ & $6425 \mathrm{c}$ & $113,5 \mathrm{a}$ & $9315 \mathrm{a}$ \\
\hline \multirow{4}{*}{$\begin{array}{l}\text { Peroba Mica } \\
\text { (Aspidosperma } \\
\text { populifolium) }\end{array}$} & Untreated & $97,0 \mathrm{c}$ & $6910 \mathrm{c}$ & $97,0 \mathrm{c}$ & $6910 \mathrm{~b}$ \\
\hline & 180 & $124,4 \mathrm{a}$ & $12205 \mathrm{a}$ & $123,3 \mathrm{a}$ & $10390 \mathrm{a}$ \\
\hline & 200 & $111,4 \mathrm{~b}$ & 10922 b & $115,9 \mathrm{~b}$ & 9955 a \\
\hline & 220 & $109,0 \mathrm{~b}$ & $10696 \mathrm{~b}$ & $125,3 \mathrm{a}$ & $10580 \mathrm{a}$ \\
\hline \multirow{4}{*}{$\begin{array}{l}\text { Cumaru } \\
\text { (Dipteryx odorata) }\end{array}$} & Untreated & $169,4 \mathrm{~b}$ & $13935,2 \mathrm{a}$ & $169,4 \mathrm{~b}$ & $13935,2 \mathrm{a}$ \\
\hline & 180 & $164,2 \mathrm{~b}$ & $12715,3 \mathrm{a}$ & $169,7 \mathrm{~b}$ & $14071,6 \mathrm{a}$ \\
\hline & 200 & $165,2 \mathrm{~b}$ & $13297,5 \mathrm{a}$ & $183,6 \mathrm{a}$ & $14725,0 \mathrm{a}$ \\
\hline & 220 & $182,2 \mathrm{a}$ & $13617,2 \mathrm{a}$ & $161,2 \mathrm{~b}$ & $14585,7 \mathrm{a}$ \\
\hline
\end{tabular}

Values with the same letters along the columns do not differ by Tukey test at $5 \%$ probability.

For peroba mica (Table 5), the MOR increased with both treatments e.g. from $97 \mathrm{MPa}$ in the untreated wood to $109 \mathrm{MPa}$ and $125 \mathrm{MPa}$ for vacuum and nitrogen at $220{ }^{\circ} \mathrm{C}$, respectively. MOE increased considerably by $35 \%$ in relation to the untreated wood with the vacuum and nitrogen methods at $220^{\circ} \mathrm{C}$.

For cumaru wood (Table 4), no influence of temperature and of treatment method was observed. Reports in the literature regarding MOE and MOR changes with heat treatments are not always coincident. Poncsak (2006) reports that the wood becomes more rigid and brittle, and mechanical properties may be reduced, depending on temperature, heating rate and duration of treatment. An inert or slightly reducing atmosphere reduces the loss of mechanical strength (Doi et al. 1999).

A reduction in MOR has been reported and explained by the changes in content and structure of hemicelluloses induced by the heat treatment, causing loss of flexural strength of wood (Boonstra et al. 2007, Korkut et al. 2008). MOE increases in heat-treated wood, and Gunduz et al. (2009) explained this result by increased lignin cross-linking that makes the structure around the cellulose microfibrils and the middle lamella more rigid. Esteves and Pereira (2009) explained this increase in MOE with increasing crystallinity of the cellulose and the reduction of moisture content equilibrium. 


\section{CONCLUSIONS}

The heat treatment of bracatinga, peroba mica and cumaru wood significantly lowered the equilibrium moisture content, although with only a small impact on improving dimensional stability. A vacuum environment was more effective to reduce wood hygroscopicity.The heat-treated woods showed in general higher hardness and bending resistance. The wood from the different species showed a different response to the heat treatment, suggesting that optimization of the heat treatment operational parameters should be species' specific. The heat treatment intensified qualities of wood for use of the external constructions and floors.

\section{ACKNOWLEDGEMENTS}

The authors wish to thank the Federal University of Viçosa, Capes (Coordination for the Development of Higher Level Personnel) and CNPq (National Council for Scientific and Technological Development) for the financial support to carry out this work. The Forest Research Centre (CEF) is a research unit funded by FCT (Fundaçãopara a Ciência e a Tecnologia, Portugal) through the strategic project PEst OE/AGR/UI0239/2014. The authors also thank Indus Parquet for the donation of the wood samples.

\section{REFERENCES}

ABNT. 1997. NBR 7190: Design of timber structures, Rio de Janeiro.

Allegretti, O.; Brunetti, M.; Cuccui, I.; Ferrari, S.; Nocetti, M.; Terziev, N. 2012. Thermovacuum modification of spruce (Picea abies Karst.) and fir (Abies alba Mill.) wood. Bioresources 7(3): 3656-3669.

Araújo, S.O.; Vital, B.R. Mendoza, Z.M.S.H.; Vieira, T.A.; Carneiro,A.C.O. 2012. Propriedades de madeiras termorretificadas de Eucalyptus grandis e SP. Scientia Forestalis 40(95): 327-336.

Baggio, A.J.;Carpanezzi, A.A. 1998. Exploração seletiva do sub-bosque: uma alternativa para aumentar a rentabilidade dos bracatingais. Colombo: EMBRAPA-CNPF, (EMBRAPA-CNPF. Circular técnica, 28,17p.

Baggio, A.J.;Carpanezzi, A.A.; Graça, L.R.; Ceccon, E. 1986. Sistema agroflorestal tradicional da bracatinga com culturas anuais. Boletim de Pesquisa Florestal, Curitiba, n.12, pp 73-82.

Batista, D.C.; Tomaselli, I.;Klitzke, R.J. 2011. Efeito do tempo e temperatura de modificação térmica na redução do inchamento máximo da madeira de Eucalyptus grandis Hill exMaiden. Ciência Florestal 21: 533-540.

Boonstra, M.; Tjeerdsma, B. 2006. Chemical analysis of heat treated softwoods. Holz Roh Werkst 64: 204-211.

Boonstra, M.J.; Acker, J.; Kegel, E.; Stevens, M. 2007. Optimisation of a two-stage heat treatment process: durability aspects. Wood Science and Technology 41: 31-57.

Borges, L.M.; Quirino, W.F. 2005. Higroscopicidade da madeira de Pinus caribaea var. hondurensis tratado termicamente. Revista da Madeira 89:173-182. 
Brito, O.T.; Garcia, J.N.; Junior, G.B.; Pessoa, A.M.C.; Silva, P.H.M. 2006. Densidade básica e retratibilidade da madeira de Eucalyptus grandis, submetida a diferentes temperaturas de termorretificação. Revista Cerne, Lavras, MG, 12 (2): 182-188.

Candelier, K.; Dumarçay, S.; Pétrissans, A.; Desharnais, L.; Gérardin, P.; Pétrissans, M. 2013. Comparison of chemical composition and decay durability of heat treated wood cured under different inert atmospheres: nitrogen or vacum. Polymer Degradation and Stability 98: 677-681.

Costa, A.F.; Garlet, A.; Prates, E.M.B. 2010. Efeito de tratamentos térmicos sobre a resistência biológica de madeiras da Amazônia. In: ENCONTRO 332 BRASILEIRO EM MADEIRAS E EM ESTRUTURAS DE MADEIRA, 12, 2010, Lavras. Anais Lavras: Universidade Federal de Lavras, pp $1-9$.

Doi, S.; Kurimoto, Y.; Ohmura, W.; Ohara, S.; Aoyama, M.; Yoshimura, T. 1999. Effects of heat treatments of wood on the feeding behaviour of two subterranean termites. Holzforschung 53: 225-229.

Esteves, B.; Marques, A.V.; Domingos, I.; Pereira, H. 2008a. Heat induced colour changes of pine (Pinus pinaster) and eucalypt (Eucalyptus globulus) wood. Wood Science and Technology 42: 369-384.

Esteves, B.M.; Pereira, H.M. 2009. Wood modification by heat treatment: a review. BioResources 4: $370-404$.

Finnish ThermowoodAssociationa - FTA. 2003. Thermo Wood ${ }^{\circledR} H a n d b o o k$, FIN-00171, Helsinki, Finland.

Galvão, A.P.M.;Jankovsky, I. 1985. Secagem racional da madeira. Nobel, São Paulo.

Garcia, C.B. 1995. Anatomia, composição e propriedade de cinco madeiras paraguaias. MScDissertation, Departamento de Engenharia Florestal, Universidade Federal de Viçosa, Viçosa, MG, Brazil.

Gouveia, F.N. 2008. Aplicação de tratamentos térmicos para estabilização colorimétrica de madeiras tropicais. PhD Dissertation, Faculdade de Tecnologia, Universidade de Brasília, Brasília.

Gunduz, G.; Aydemir, D.; Karakas, G. 2009. The effects of thermal treatment on the mechanical properties of wild pear (Pyrus elaeagnifolia Pall.) wood and changes in physical properties. Materials \& Design 30: 4391-4395.

Hill, C.A.S. 2006. Wood modification. Chemical, thermal and other processes. John Wiley \& Sons, Chichester, UK.

Homan, W.J.; Jorissen, A.J.M. 2004. Wood modification developments. Heron 49: 361-386.

Inoue, M.T.; Roderjan, C.V.; Kuniyoshi, Y.S. 1984. Projeto Madeira do Paraná. Curitiba: FUPEF - Fundação de Pesquisas Florestais do Paraná, Brasil.

Instituto Brasileiro De Desenvolvimento Florestal - IBDF. 1981. Madeiras da Amazônia: características e utilização: Floresta Nacional do Tapajós. Brasília, DF, v. 1.

Instituto Brasileiro De Desenvolvimento Florestal - IBDF. 1988. Madeiras da Amazônia: características e utilização: Estação Experimental de Curuá-Una. Brasília, DF, v. 2, pp236.

Instituto Brasileiro Do Meio Ambiente E Dos Recursos Naturais Renováveis - IBAMA. 1997. Madeiras da Amazônia: características e utilização. v. 3. Amazônia Oriental. Brasília, Brasil.

Korkut, D.S.;Korkut, S.; Bekar, I.; Budakçi, M.; Dilik, T.; Çakicier, N. 2008. The effects of heat treatment on the physical properties and surface roughness of Turkish hazel (Corylus colurna L.) wood. International Journal of Molecular Sciences 9: 1772-1783. 
Lengowski, E.C. 2011. Efeito da termorretificação nas propriedades anatômicas, físico-mecânicas e químicas das madeiras de Pinus taeda, Eucalyptus grandis e Tectona grandis. MSc Dissertation, Federal University of Paraná.

Logsdon, N.B.; Finger, Z.; Borges, C.G.A. 2008. Caracterização físico-mecânica para madeira de peroba-mica, Aspdosperma populifolium, A. DC. (APOCYNACEAE). Floresta, Curitiba, PR. $38(1): 11-21$.

Loureiro, A.A.; Silva, M.F., Alencar, J.C. 1979. Essências madeireiras da Amazônia. INPA, Manaus, Brasil.

Lovatti, L.P. 2008. Madeira serrada na Região Sul do Espírito Santo: Comercialização e propriedades. MSc Dissertation, Universidade Federal do Espírito Santo, Jerônimo Monteiro, ES, Brazil.

Miller, R.B. 1999. Characteristics and availability of commercially important woods. Wood Handbook, Wood as Engineering Material, FPL-GTR-113; U.S. Department of Agriculture. Forest Service, Forest Products Laboratory: Madison, WL.

Mitchel, P.H. 1988. Irreversible property changes of small loblolly pine specimens heated in air, nitrogen, or oxygen. Wood Fiber Science 20: 320-355.

Moreschi, J.C. 2005. Propriedades tecnológicas da madeira. Dissertation, Departamento de Engenharia e Tecnologia Florestal da Universidade Federal do Paraná- UFPR, pp168.

Nunes, C.S. 2009. Estabilidade dimensional e modificações químicas da madeira termorretificada de Corymbiacitriodora (Hook.) K.D.Hill\& L.A.S. Johnson. 32 p. MSc Dissertation, Instituto de Florestas, Universidade Federal Rural do Rio de Janeiro, Seropédica.

Poncsák, S. 2006. Effect of high temperature treatment on the mechanical properties of birch (Betula papyrifera). Wood Science and Technology 1(40): 647-663.

Souza, M.H.; Magliano, M.M.; Camargos, J.A.A.; Souza, M.R. 1997. Madeiras tropicais brasileiras. Brasília, DF: IBAMA, pp 152.

Stamm, A.J. 1956. Thermal degradation of wood and cellulose. Industrial and Engineering Chemistry 48(3): 413-41.

Sturion, J.A.; Silva, F. 1989. Caracterizacion de la madera de bracatinga para energía. In: SALAZAR, R. (Ed.). Manejo y aprovechamiento de plantaciones forestales con especies de uso multiple: actas Reunión IUFRO, Guatemala, abril 1989. Turrialba: CATIE, 1989,pp 541-549.

Sundqvist, B. 2004. Colour changes and acid formation in wood during heating. Dissertation, Lulea University of Technology.

Tappi 258 om-02. Standard 2002. Basic density and moisture content of pulp wood.

Tomak, E.D.; Viitanen, H.; Yildiz, U.C.; Hughes, M. 2011. The combined effects of boron and oil heat treatment on the properties of beech and Scots pine wood. Part 2: Water absorption, compression strength, color changes, and decay resistance. Journal of Materials Science 46: 608 - 615.

Tomazello Filho, M. 1985. Variação radial da densidade básica e da estrutura anatômica da madeira do E. saligna e E. grandis. IPEF 29: 37-45.

Tuong, V.M.; Li, J. 2011. Changes caused by thermal treatment in chemical composition and some physical properties of acacia hybrid sapwood. Holzforschung 65: 67-72. 
Weiland, J.J.; Guyonnet, R.; Gibert, R. 1998. Analysis of controlled wood burning by combination of thermogravimetric analysis, differential scanning calorimetry and Fourier transform infrared spectroscopy. Journal of Thermal Analysis and Calorimetry 51 (1): 265-274. 